\title{
BLACK-FOOTED FERRET DIGGING ACTIVITY IN SUMMER
}

\author{
David A. Eads ${ }^{1,5}$, Dean E. Biggins ${ }^{2}$, Dustin Marsh ${ }^{3}$, Joshua J. Millspaugh ${ }^{1}$, and Travis M. Livieri ${ }^{4}$
}

\begin{abstract}
Black-footed ferrets (Mustela nigripes) excavate soil from prairie dog (Cynomys spp.) burrows, thereby creating characteristic soil deposits at burrow openings. These soil deposits have been observed only rarely in summer. We monitored adult ferrets during June-October of the years 2007 and 2008 on a 452-ha colony of black-tailed prairie dogs (Cynomys ludovicianus) in the Conata Basin, South Dakota. We located and identified ferret excavations during nighttime spotlight surveys for ferrets and daytime sampling of prairie dog burrow openings around locations where ferrets were located via spotlight. We accumulated 48 observations of in-process or recently completed ferret excavations during spotlight surveys (21 in 2007, 27 in 2008) and located 51 diggings during daytime burrow sampling (25 in 2007, 26 in 2008). We located diggings during $5.5 \%$ of spotlight observations, most frequently in July-August. These results collectively suggest ferrets may frequently excavate soil in summer, because prairie dogs frequently use soil to plug burrow openings and tunnels in defense against ferrets. Prairie dogs might frequently destroy soil deposits left by ferrets during summer, thereby reducing detection of diggings by biologists.
\end{abstract}

REsumen.—Los hurones de patas negras (Mustela nigripes) excavan tierra de las madrigueras de los perros llaneros (Cynomys spp.), creando así depósitos de tierra característicos en las entradas de las madrigueras. Los depósitos de tierra hechos por los hurones raras veces se han observado durante el verano. En la Cuenca Conata, Dakota del Sur, observamos hurones adultos en una colonia de perros llaneros de cola negra (Cynomys ludovicianus) de 452 ha durante junio a octubre de 2007 y de 2008. Al realizar búsquedas de hurones con reflectores durante la noche, localizamos e identificamos excavaciones que estos animales habían hecho, mientras que de día las localizamos e identificamos mediante la revisión de madrigueras de perros llaneros alrededor de los lugares en donde se habían ubicado hurones con el uso de reflectores. Durante las búsquedas con reflectores, acumulamos 48 observaciones de excavaciones de hurones ya fuera en proceso o recientemente terminadas (21 en 2007 y 27 en 2008); también ubicamos 51 excavaciones durante la revisión de madrigueras durante el día (25 en 2007 y 26 en 2008). Encontramos excavaciones durante el 5.5\% de las observaciones hechas con reflectores, principalmente en julio y agosto. Estos resultados sugieren colectivamente que los hurones podrían hacer excavaciones frecuentemente durante el verano, tal vez debido a que a menudo los perros llaneros usan la tierra para tapar las madrigueras y túneles para defenderse de los hurones en el verano, forzando a que estos últimos tengan que excavar. Podría ser que los perros llaneros con frecuencia destruyen los depósitos de tierra que dejan los hurones durante el verano, disminuyendo así la detección de las excavaciones por biólogos.

Black-footed ferrets (Mustela nigripes) are endangered mustelids that depend on prairie dogs (Cynomys spp.) as a food source (Sheets et al. 1972, Campbell et al. 1987) and use prairie dog burrows for shelter (Forrest et al. 1988, Biggins et al. 2006b). Although the functions are not entirely known (Richardson et al. 1987, Miller et al. 1996), ferrets excavate soil from prairie dog burrows (Fig. 1; Clark et al. 1984a, 1984b, 1986). Because characteristics of excavated soil deposits left by ferrets differ from deposits left by American badgers (Taxidea taxus) and prairie dogs, evidence of recent ferret excavation activity has been used as an indicator of ferret presence (Clark et al. 1984a).
In addition, ferret excavation activity can continue for $>1$ hour and involve movement of large quantities of soil (Clark et al. 1984a, Fagerstone and Biggins 1986, Richardson et al. 1987), suggesting implications for ferret energetics (Powell et al. 1985, Harrington et al. 2006, Biggins et al. 2012a).

During research on resource selection by ferrets (Eads et al. 2011a, 2011b), we also aimed to estimate frequency of ferret digging activity to supplement previous investigations of diggings on colonies of black-tailed prairie dogs (Cynomys ludovicianus) in Mellette County, South Dakota (Hillman 1968, Henderson et al. 1969) and white-tailed prairie dogs (Cynomys

\footnotetext{
${ }^{1}$ Department of Fisheries and Wildlife Sciences, University of Missouri, 302 Natural Resources Building, Columbia, MO 65211

${ }^{2}$ U.S. Geological Survey, Fort Collins Science Center, 2150 Centre Avenue, Building C, Fort Collins, CO 80526.

32122 Mulberry Lane, Placerville, CA 95667

${ }^{4}$ Prairie Wildlife Research, Box 308, Wellington, CO 80549

5Present address: Graduate Degree Program in Ecology, Colorado State University, Fort Collins, CO 80523-1878. E-mail: david.eads@colostate.edu
} 

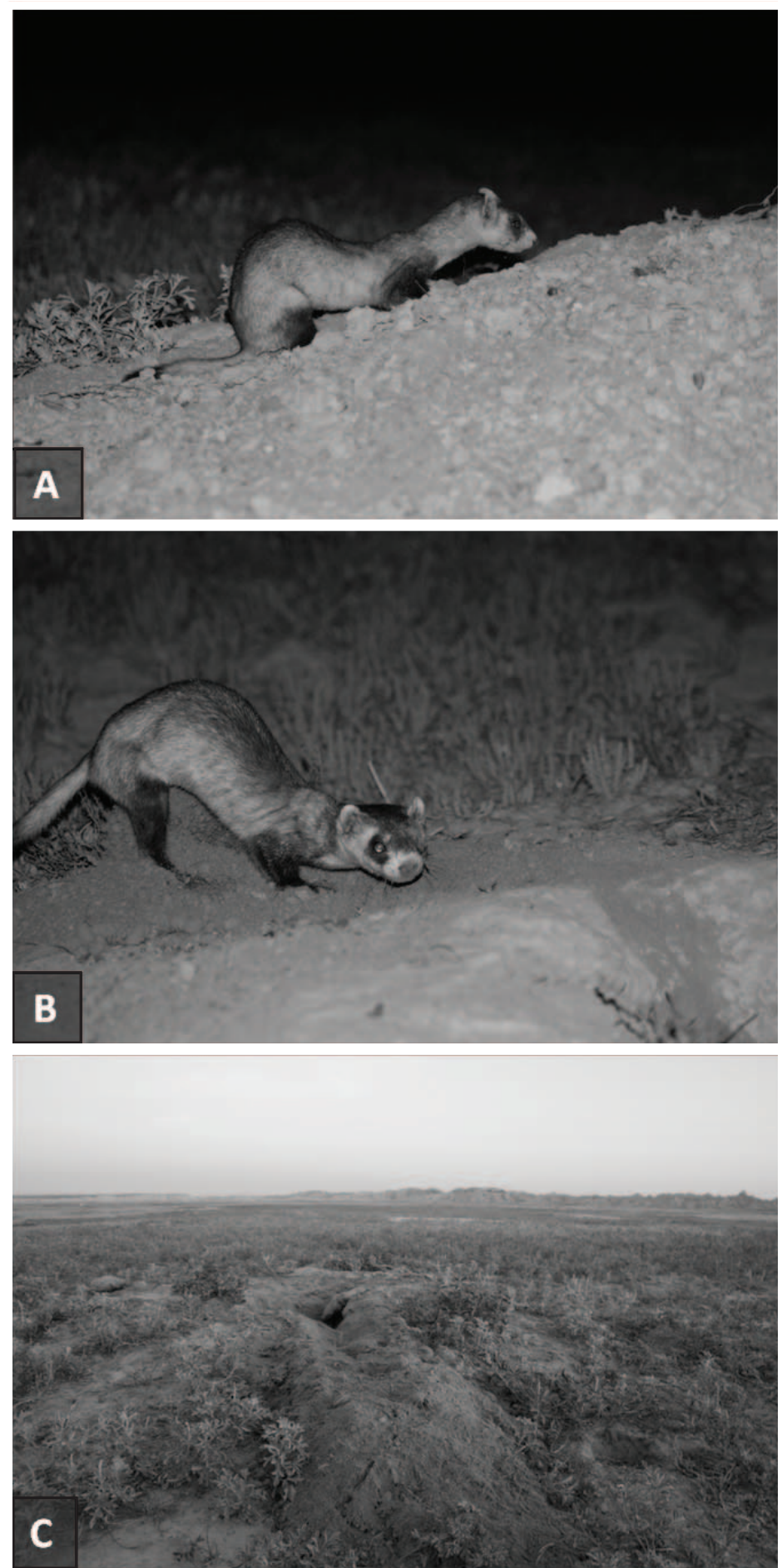

Fig. 1. A, Female black-footed ferret (Mustela nigripes) 05-006 using her forelegs to pull dirt from a black-tailed prairie dog (Cynomys ludovicianus) burrow opening; B, female ferret 02-001 using her hind legs to push dirt away from a prairie dog burrow opening; C, a characteristic ferret dig (extending into foreground) created by female 02-001 (Photos: DAE). 
leucurus) near Meeteetse, Wyoming (Clark et al. 1984a, 1984b, 1986). In these former studies, ferret excavations were commonly located in winter but infrequently found in summer. This pattern may be an artifact of the higher rates of aboveground activity by prairie dogs in summer, which may create conditions for the rapid destruction of ferret diggings (Hillman 1968, Henderson et al. 1969, Fortenbery 1972, Hillman and Linder 1973). As prescribed by Clark et al. (1984a), we attempted to locate soil deposits created by ferrets before prairie dogs destroyed those deposits. To do so, we recorded the occurrence of ferret excavations via direct observation of ferrets and through subsequent examinations of burrows where ferrets had been located during previous spotlight surveys.

\section{Study Site}

We studied ferrets inhabiting a 452-ha colony of black-tailed prairie dogs, located in the Conata Basin of southwestern South Dakota (North American Datum 1927 UTM 13N N 4848099, E 716705). The colony is primarily on the Buffalo Gap National Grasslands, which is managed by the USDA Forest Service. Grasslands in the area are predominantly covered by western wheatgrass (Pascopyrum smithii), blue grama (Bouteloua gracilis), and buffalo grass (Buchloe dactyloides), with various forbs in heavily grazed areas. The site was inhabited by American badgers, swift foxes (Vulpes velox), and thirteen-lined ground squirrels (Otospermophilus tridecemlineatus), species that might also modify prairie dog burrows. Ferret diggings are distinguishable from diggings by these other species (Clark et al. 1984a).

\section{Methods}

\section{Spotlight Survey Data}

To locate soil deposits (diggings) created by ferrets before prairie dogs destroyed those deposits (Clark et al. 1984a), we directly observed ferrets digging. On nearly consecutive nights during 13 June-10 October 2007 and 11 June-27 September 2008, observers (DAE and DM) monitored ferrets during spotlight surveys concentrated between midnight and sunrise (Clark et al. 1984a, Campbell et al. 1985, Biggins et al. 2006a). The observers drove a vehicle and used a roof-mounted spot- light to illuminate terrain around a predetermined route that maximized coverage of the colony (Eads et al. 2011a, 2011b). During late summer and fall of previous years and during 2007-2008, one of us (TML) captured ferrets (Biggins et al. 2006a) and implanted each with a passive integrated transponder (PIT; Fagerstone and Johns 1987). To identify a ferret, we placed an automatic PIT-reader loop antenna on the occupied burrow opening; identification numbers were recorded whenever a tagged ferret passed near the antenna (Biggins et al. 2006a). We identified ferrets without PIT tags via unique dye markings applied in early to mid-June of each field season by TML (Grenier et al. 2009, Jachowski et al. 2010, Eads et al. 2011a, 2011b).

During spotlight observation of a ferret, we inspected the occupied burrow opening for evidence of ferret excavation activity. Ferret excavations vary in appearance but are characterized by one or more lobed soil deposits. Inside a prairie dog burrow, a ferret gathers soil with the forefeet and then exits from the burrow backwards, pulling and depositing the soil aboveground; the ferret's backward movement often leaves a trough in the lobed soil (Fig. 1; Clark et al. 1986). We sometimes found a digging that was created by the ferret before we arrived, and in some of those instances, and others, we directly observed ferrets in the process of digging. Observer presence and PIT readers did not appear to influence digging behaviors of ferrets.

To analyze data, we used binomial generalized linear mixed models (GLMMs) in Program R 2.13.2 and the 'Ime4' package (R Development Core Team 2011) to relate observations of diggings to predictor variables. We classified all spotlight locations as (1) "digging present" if a ferret soil deposit was found or a ferret was digging or (2) "digging absent" if a ferret soil deposit was not found or a ferret was not observably digging. To account for dependences between observations of an individual ferret, we defined individual ferrets as random effects. We included 3 main effects in the GLMM exercise: day-of-year and year (to investigate temporal patterns) and sex of ferret (to investigate differences between sexes; females were raising kits during most of our study). We examined effects of date, including linear and nonlinear forms, because female ferrets, in 
particular, might dig more during July-August (the middle of our field season) than in June or September-October. The reason is that prey requirements are greatest for adult female ferrets during July-August when they must care for their growing young (Biggins et al. 1993). Three forms of date were considered: linear $(x)$, quadratic $\left(x^{2}+x\right)$, and pseudothreshold $[\log (x+0.50)+x]($ Franklin et al. 2000). To select among these forms of date, we fit GLMMs for each form and retained the form with the lowest Akaike's information criterion $\left(\mathrm{AIC}_{c}\right)$. The pseudothreshold form was most supported $\left(\mathrm{AIC}_{c}=446.36\right)$ and was retained in subsequent modeling (quadratic $\mathrm{AIC}_{c}=$ 450.18; linear $\left.\mathrm{AIC}_{c}=452.90\right)$. We combined the pseudothreshold Julian date predictor variable with the remaining variables and all possible 2-way interactions and used backward elimination based on $Z$ tests $(\alpha=0.05)$ to identify a parsimonious model.

\section{Additional Burrow Surveys}

To further investigate summer digging activity by ferrets, we counted diggings within $20-\mathrm{m}$ radius circular plots centered on some burrows at which ferrets were located via spotlight. Each of these burrows was paired with one random location within the study colony boundary (see Eads 2009). This sampling scheme permitted (1) an evaluation of the reliability of diggings as indicators of ferret presence and (2) an evaluation of the effectiveness of searching for ferret diggings at random locations. However, note that the daytime burrow surveys were completed within 4 days of observing a ferret $(\bar{x}=0.83$ days, $\mathrm{SD}=1.06)$. Thus, prairie dogs could have destroyed some of the ferret diggings before we completed some daytime burrow sampling events.

In ArcGIS 9.2 (Environmental Systems Research Institute, Redlands, CA), we buffered ferret locations with circular polygons of 1-km radii. Then we generated one random location per polygon, limiting random locations to the colony. Because all used plots were centered on a burrow opening, in the field we shifted centers of random plots to the nearest burrow opening. We completed sampling of used and random plots in random order, and we summarize these data below. We did not conduct formal statistical analyses because we found diggings in plots centered on ferret locations but never found a digging in a random plot.

\section{Results \\ Spotlight Survey Data}

We monitored 26 adult ferrets (5 of which were monitored in both 2007 and 2008), collecting 458 observations in 2007 and 418 observations in 2008. Numbers of ferrets varied among years, and more females were monitored than males (2007: 9 females, 3 males; 2008: 9 females, 5 males). During spotlight surveys, we found 21 fresh (in progress or completed) ferret diggings in 2007 and 27 in 2008 (5.48\% of all observations, 2007-2008). Multiple diggings were not observed during any single ferret observation (i.e., if a digging was found, only one was found). The final GLMM contained the pseudothreshold date variable. Detection of ferret diggings was greatest in July-August and declined thereafter in September-October (Fig. 2). No other main effect and no interaction were supported.

\section{Additional Burrow Surveys}

We sampled circular plots centered on 118 pairs of used and random plots in 2007 and 96 pairs in 2008. These samples included $26 \%$ of spotlight observations for ferrets in 2007 and $23 \%$ of spotlight observations in 2008 . We did not find ferret diggings in any of the paired, random plots. In plots observably used by ferrets, we found 25 diggings in 2007 and 26 diggings in 2008. In 2007, $29 \%$ of diggings observed during spotlight surveys were not found during daytime surveys. In 2008, 30\% of diggings observed during spotlight surveys were not found during daytime surveys. Thus, the daytime surveys were likely to have underestimated digging activity by ferrets.

\section{Discussion}

During initial studies of the last known extant population of ferrets near Meeteetse, Wyoming, investigators tallied numbers of ferret diggings found in plots (e.g., 4-ha plots in Clark et al. 1984a, 1984b) or while snow tracking ferrets (Richardson et al. 1987) on whitetailed prairie dog colonies. Such daytime sampling suggested that numbers of ferret diggings are characterized by marked seasonality, peaking in December-March and declining until late fall (Clark et al. 1984a, 1984b, 1986). Earlier studies of ferrets on black-tailed prairie dog colonies in Mellette County, South Dakota, 


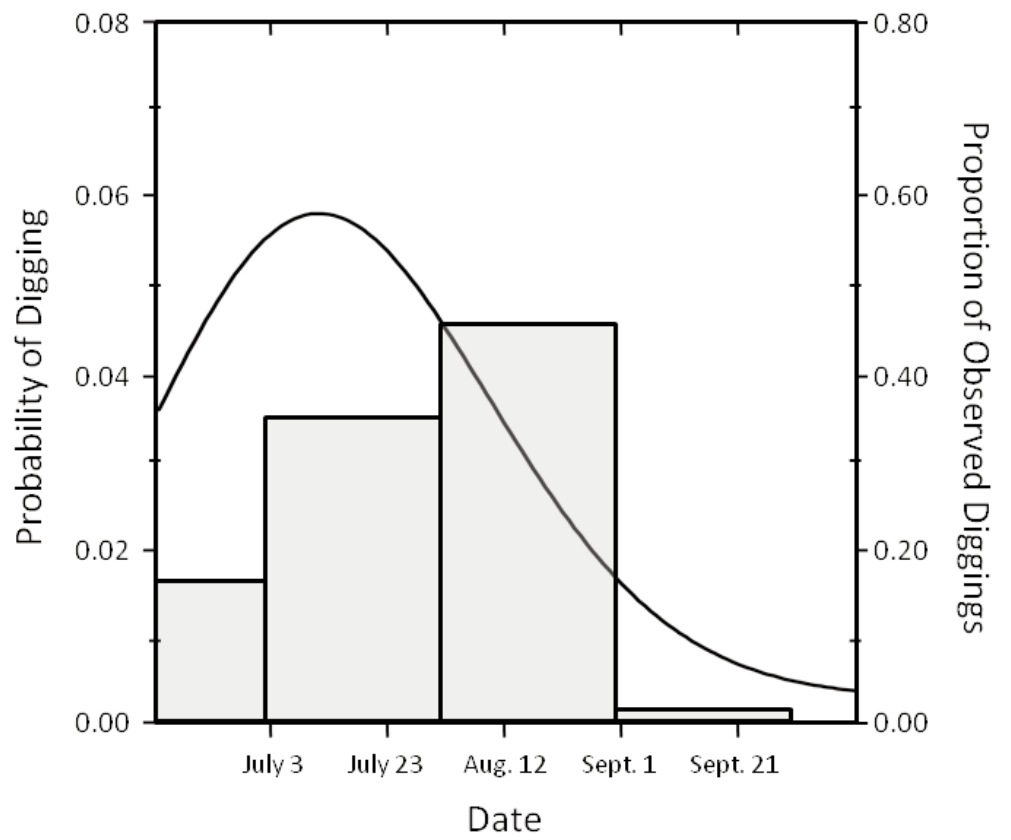

Fig. 2. Probability of detecting black-footed ferret (Mustela nigripes) diggings, per spotlight survey, on a colony of black-tailed prairie dogs (Cynomys ludovicianus) in the Conata Basin, South Dakota, 13 June-10 October 2007 and 11 June27 September 2008. Predictions (line) are derived from the generalized linear mixed model (GLMM) with a pseudothreshold effect for date (left vertical axis). Proportions of observed diggings in monthly intervals (bars; mid-June through mid-October 2007-2008) correspond with the right vertical axis.

suggested a similar seasonal trend (Hillman 1968, Henderson et al. 1969).

In contrast to past reports, we detected numerous ferret diggings during summer months. Why is there a discrepancy between studies? During the summer months, when diurnal prairie dogs are most active (Hoogland 1995, Lehmer et al. 2006), prairie dogs might rapidly destroy soil deposits made by ferrets (Hillman 1968, Henderson et al. 1969, Fortenbery 1972, Hillman and Linder 1973). This suggests that daytime searches can underestimate digging rates. We located many diggings via direct, nighttime observation of ferrets; that is, we observed many diggings before they were destroyed. However, 14 of the 48 diggings observed during spotlight surveys (29\%) were not located 1-4 days later during daytime surveys. Though wind might have degraded some soil deposits, prairie dogs might have destroyed the 14 diggings. Hibernating and torpid prairie dogs in winter months have fewer occasions to destroy soil deposits made by ferrets.

Our spotlight sampling facilitated detection of diggings before degradation or destruction.
Nevertheless, even our spotlight-based estimates of digging rates are underestimates because we did not continuously monitor ferrets and we did not sample circular plots around all of the ferret observations. Investigation of digging behavior by radio-collared ferrets could provide increased resolution (e.g., Biggins et al. 2012a).

Ferret diggings are an indicator of ferret occurrence, suggesting utility in searching for diggings to locate ferrets (Henderson et al. 1969, Clark et al. 1984a). However, we did not find diggings at 214 random locations distributed throughout a colony with a relatively high density of ferrets, including individuals that we directly observed digging. Thus, we only encourage daytime searches for ferret diggings when snow cover is adequate to allow aerial and snow tracking surveys (methods in Biggins and Engeman 1986, Richardson et al. 1987), or perhaps when prairie dogs are hibernating (e.g., white-tailed prairie dogs and Gunnison's prairie dogs [Cynomys gunnisoni]). Spotlight surveys are likely more efficient for detecting ferrets during all seasons, 
especially in summer when prairie dogs are most active (Biggins et al. 2006a).

In this study, the number of ferret diggings was greatest in July-August and declined in September-October (Fig. 1). This pattern provides insight into the functions of diggings. Ferrets might excavate burrows to approach and attack prairie dogs in plugged burrows. During summer, black-tailed prairie dogs plug burrow openings and underground tunnels in defense against ferrets, and ferrets might need to dig into these burrows to acquire prey (Biggins et al. 2012b, Eads and Biggins 2012). If digging is associated with hunting, including hunting forays in burrows plugged by prairie dogs, then digging activity should be most frequent when prey requirements are greatest and when prairie dogs are most defensive. This appears to be the case in our study period (June-October), given that we observed diggings most frequently during July-August. During this period, female ferrets must acquire prey for themselves and their growing offspring. Additionally, prairie dogs are abundant and active, and might stimulate digging activity by ferrets by plugging their burrows in defense. Digging activity declined as kits initiated independent hunting and dispersal in September. After kits have dispersed in midSeptember and early October, females might reduce energy expenditure by further reducing digging activity.

Note that we did not detect differences in digging activities of female and male ferrets. Prey requirements for male ferrets are likely constant among the summer months and lower than requirements for females with kits. If digging facilitates hunting, why would male ferrets also increase digging activity in July-August but decrease digging activity in SeptemberOctober? The small sample size for male ferrets might have reduced the power to detect differences among sexes. In addition, perhaps prairie dogs most frequently plug burrow tunnels shortly after pups are born but then reduce burrow plugging efforts as pups grow. If so, both female and male ferrets would need to frequently dig in early summer, but not in late summer, to acquire prey. Nonetheless, future studies could investigate differences in digging activities by female and male ferrets, particularly while females are raising kits.

Diggings might serve functions in addition to prey acquisition (Miller et al. 1996). For instance, ferrets might also dig to investigate or modify den sites. Ferrets seem to prefer multi-opening burrow systems (Biggins 2012), but prairie dogs reduce the availability of multi-opening systems by plugging burrows when ferrets are present (Biggins et al. 2012b, Eads and Biggins 2012). Thus, digging might be frequently required to create multi-opening den sites. Female ferrets change den locations most frequently in July-August (Jachowski 2007), and male ferrets frequently traverse home ranges in the summer (personal observation, Fagerstone and Biggins 2011). This suggests that ferrets increase investigation and modification of potential den sites when we most frequently observed diggings. Investigation and modification of den sites were also implicated in a winter snow tracking study, in which $84 \%$ of observed diggings were detected at den/cache burrows (Richardson et al. 1987).

Regardless of the functions of digging by ferrets, the behavior might have important energetic implications (Powell et al. 1985, Harrington et al. 2006, Biggins et al. 2012a). Indeed, in one study, digging sessions occupied about $25 \%$ of a ferret's time during a night of activity, and during a single session of digging, ferrets moved loads of soil that collectively weighed $>20$ times their weight (Biggins et al. 2012a). The energetic implications of digging behavior for ferrets suggest that additional research on this behavior would be useful.

Previous research provides insight into digging configuration (Clark et al. 1984a), bout duration (Fagerstone and Biggins 1986, Jachowski 2007, Biggins et al. 2012a), volume of soil excavated (Richardson et al. 1987, Biggins et al. 2012a), and relative estimates of monthly occurrence outside our period of study (Clark et al. 1984b, 1986). Our data suggest ferrets frequently engage in digging during the summer, particularly in July-August. Although digging can serve multiple functions, we hypothesize that ferrets commonly dig in summer to prey on sequestered prairie dogs and to investigate and modify den sites. Ferrets now occupy multiple sites throughout their historic range in colonies of 3 species of prairie dogs $(C$. gunnisoni, C. leucurus, and C. ludovicianus). Future studies could investigate the digging behaviors of ferrets at additional sites to determine if digging behaviors differ between sites with differing climate, species of prairie dogs, 
and soil types-factors that might influence the energetic expense of digging behavior.

\section{ACKNOWLEDGMENTS}

This study was made possible through State Wildlife Grant T35, study number 2435, provided by the South Dakota Department of Game, Fish and Parks. Support was also provided by the National Fish and Wildlife Foundation, the U.S. Fish and Wildlife Service, the U.S. Geological Survey, Prairie Wildlife Research, the Denver Zoological Foundation, and the University of Missouri. DAE was also supported by S. and D. Webb. We appreciate the assistance of S. Eads during daytime surveys in 2007 and reviews of a previous draft by J. Chipault, S. Eads, S. Grassel, S. Ramakrishnan, J. Stabach, and 2 anonymous reviewers.

Any use of trade, product, or firm names is for descriptive purposes only and does not imply endorsement by the United States federal government.

\section{Literature Cited}

BIGGINS, D.E. 2012. Use of multi-opening burrow systems by black-footed ferrets. Western North American Naturalist 72:134-139.

Biggins, D.E., AND R.M. Engeman. 1986. Aerial survey for black-footed ferret sign in snow. Page 7.2 in Abstracts of contributed papers. Thirteenth International Biometric Conference, Seattle, WA.

Biggins, D.E., J.L. Godbey, M.R. Matchett, L.R. Hanebury, T.M. Livieri, and P.E. Marinari. 2006a. Monitoring black-footed ferrets during reestablishment of free-ranging populations: discussion of alternative methods and recommended minimum standards. Pages 155-174 in J.E. Roelle, B.J. Miller, J.L. Godbey, and D.E. Biggins, editors, Recovery of the black-footed ferret: progress and continuing challenges. U.S. Geological Survey Scientific Investigations Report 2005-5293.

Biggins, D.E., J.L. Godbey, M.R. Matchett, and T.M. LIVIERI. 2006b. Habitat preferences and intraspecific competition in black-footed ferrets. Pages 129140 in J.E. Roelle, B.J. Miller, J.L. Godbey, and D.E. Biggins, editors, Recovery of the black-footed ferret: progress and continuing challenges. U.S. Geological Survey Scientific Investigations Report 2005-5293.

Biggins, D.E., L.R. HaneburY, and K.A. Fagerstone. 2012a. Digging behaviors of radio-tagged blackfooted ferrets near Meeteetse, Wyoming, 1982-1984. Western North American Naturalist 72:148-157.

Biggins, D.E., B. Miller, L. Hanebury, R. Oakleaf, A. Farmer, R. CRete, AND A. Dood. 1993. A technique for evaluating black-footed ferret habitat. Pages 73-78 in J. Oldemeyer, B. Miller, and R. Crete, editors, Management of prairie dog complexes for reintroduction of the black-footed ferret. U.S. Fish and Wildlife Service Biological Report 13.
Biggins, D.E., S. Ramakrishnan, A.R. Goldberg, and D.A. EADS. 2012b. Black-footed ferrets and recreational shooting influence the attributes of blacktailed prairie dog burrows. Western North American Naturalist 72:158-171.

Campbell, T.M., III, D. Biggins, S. Forrest, and T.W. CLARK. 1985. Spotlighting as a method to locate and study black-footed ferrets. Pages 24.1-24.7 in S.H. Anderson and D.B. Inkley, editors, Black-footed Ferret Workshop Proceedings. Wyoming Game and Fish Department, Cheyenne, WY.

Campbell, T.M., III, T.W. ClakK, L. Richardson, S.C. Forrest, AND B.R. Houston. 1987. Food habits of Wyoming black-footed ferrets. American Midland Naturalist 117:208-210.

Clark, T.W., T.M. Campbell, M.H. Schroeder, and L. RiCHARDSON. 1984a. Handbook of methods for locating black-footed ferrets. BLM Technical Bulletin No. 1. U.S. Bureau of Land Management, Cheyenne, WY.

Clark, T.W., L. Richardson, D. Casey, T.M. Campbell III, AND S.C. FORREST. 1984b. Seasonality of blackfooted ferret diggings and prairie dog burrow plugging. Journal of Wildlife Management 48:1441-1444.

Clark, T.W., L. Richardson, S.C. Forrest, D.E. Casey, and T.M. CampbeLL. 1986. Descriptive ethology and activity patterns of black-footed ferrets. Great Basin Naturalist Memoirs 8:115-134.

EADS, D.A. 2009. Evaluation and development of blackfooted ferret resource selection models. Master's thesis, University of Missouri, Columbia, MO.

Eads, D.A., AND D.E. BigGins. 2012. Patterns of surface burrow plugging in a colony of black-tailed prairie dogs occupied by black-footed ferrets. Western North American Naturalist 72:172-178.

Eads, D.A., J.J. Millspaugh, D.E. Biggins, D.S. JachowSKI, AND T.M. LIVIERI. 2011a. Evaluation of a blackfooted ferret resource utilization function model. Journal of Wildlife Management 75:1155-1163.

Eads, D.A., J.J. Millspaugh, D.E. Biggins, T.M. Livieri, AND D.S. Jachowski. 2011b. Post-breeding resource selection by adult black-footed ferrets in the Conata Basin, South Dakota. Journal of Mammalogy 92: 760-770.

FAGERSTONE, K.A., AND D.E. BigGins. 1986. Summary of black-footed ferret and related research conducted by the Denver Wildlife Research Center. U.S. Fish and Wildlife Service, Denver, CO.

2011. Black-footed ferret areas of activity during late summer and fall at Meeteetse, Wyoming. Journal of Mammalogy 92:705-709.

Fagerstone, K.A., AND B.E. Johns. 1987. Transponders as permanent identification markers for domestic ferrets, black-footed ferrets, and other wildlife. Journal of Wildlife Management 51:294-297.

Forrest, S.C., D.E. Biggins, L. Richardson, T.W. Clark, T.M. Campbell, K.A. Fagerstone, and E.T. Thorne. 1988. Population attributes for the black-footed ferret (Mustela nigripes) at Meeteetse, Wyoming, 19811985. Journal of Mammalogy 69:261-273.

ForTenberY, D.K. 1972. Characteristics of black-footed ferrets. U.S. Fish and Wildlife Service Resource Publication 109.

Franklin, A.B., D.R. Anderson, R.J. GutiérRez, And K.P. Burnham. 2000. Climate, habitat quality, and fitness in Northern Spotted Owl populations in northwestern California. Ecological Monographs 70:539-590. 
Grenier, M.B., S.W. Buskirk, and R. Anderson-Sprecher. 2009. Population indices versus correlated density estimates of black-footed ferret abundance. Journal of Wildlife Management 73:669-676.

Harrington, L.A., D.E. Biggins, and A.W. Alldredge. 2006. Modeling black-footed ferret energetics: are southern release sites better? Pages 286-288 in J.E. Roelle, B.J. Miller, J.L. Godbey, and D.E. Biggins, editors, Recovery of the black-footed ferret: progress and continuing challenges. U.S. Geological Survey Scientific Investigations Report 2005-5293.

Henderson, F.R., P.F. Springer, and R. Adrian. 1969 The black-footed ferret in South Dakota. South Dakota Department of Game, Fish and Parks Technical Bulletin 4.

Hillman, C.N. 1968. Life history and ecology of the black-footed ferret in the wild. Master's thesis, South Dakota State University, Brookings, SD.

Hillman, C.N., AND R.L. Linder. 1973. The black-footed ferret. Pages 10-20 in R.L. Linder and C.N. Hill man, editors, Proceedings of the black-footed ferret and prairie dog workshop. South Dakota State University, Brookings, SD.

Hoogland, J.L. 1995. The black-tailed prairie dog: social life of a burrowing mammal. Chicago University Press, Chicago, IL.

JACHOWSKI, D.S. 2007. Notes on black-footed ferret detectability and behavior. Prairie Naturalist 39:99-104

Jachowski, D.S., J.J. Millspaugh, D.E. Biggins, T.M. Livieri, AND M.R. Matchett. 2010. Home-range size and spatial organization of black-footed ferrets
Mustela nigripes in South Dakota, USA. Wildlife Biology 16:1-11.

Lehmer, E.M., L.T. Savage, M.F. Antolin, and D.E. BIGGINS. 2006. Extreme plasticity in thermoregulatory behaviors of free ranging black tailed prairie dogs. Physiological and Biochemical Zoology 79: 454-467.

Miller, B. R.P. REAding, and S.C. ForRest, 1996. Prairie night: black-footed ferrets and the recovery of endangered species. Smithsonian Institution Press, Washington, DC.

Powell, R.A., T.W. Clark, L. Richardson, and S.C. FORREST. 1985. Black-footed ferret (Mustela nigripes) energy expenditure and prey requirements. Biological Conservation 34:1-15.

R Development Core Team. 2011. R: a language and environment for statistical computing [online]. $\mathrm{R}$ Foundation for Statistical Computing, Vienna, Austria. ISBN 3-900051-07-0. Available from: http:// www.R-project.org/.

Richardson, L., T.W. Clark, S.C. Forrest, and T.M. CAMPBELL. 1987. Winter ecology of the black-footed ferret at Meeteetse, Wyoming. American Midland Naturalist 117:225-239.

Sheets, R.G., R.L. Linder, and R.B. Dalhgren. 1972 Food habits of two litters of black-footed ferrets in South Dakota. American Midland Naturalist 87: 249-251.

Received 18 April 2011 Accepted 16 March 2012 